\title{
Dynamics of Basic Education Policy Implementation in Central Mamuju District
}

\author{
Busdir ${ }^{1}$, Muh. Akmal Ibrahim ${ }^{1}$, Gita Susanti ${ }^{1}$, Badu Ahmad ${ }^{1}$ \\ ${ }^{1}$ Department of Public Administration, Hasanuddin University, Indonesia \\ Received: December 15, 2021 \\ Received in Revised: January 24, 2022 \\ Accepted: January 18, 2022
}

\begin{abstract}
First and foremost, the dynamics of basic education in Central Mamuju Regency are characterized by four factors, including (1) communication difficulties, (2) a lack of psychological relationships between educators and students, and (3) the pandemic's effect on the learning system, which affects online learning psychologically. Teacher difficulties in implementing Scientific Learning-Based Education and giving learning evaluations are among the resources that may be accessed. Certain students may not be able to comprehend the substance of material provided via online media by the instructor, the internet network may be disturbed at times, and some subject matter that needs particular learning tools and/or media cannot be utilized due to the absence of online learning media. The instructor conveys the information in the most effective manner. There are several conditions that must be met by every school that holds face-to-face learning, including the permission of students' parents through committees, the readiness of the school to hold face-to-face learning with strict health protocols, and obtain permission from the local government through the COVID-19 task force. (4). Bureaucratic structure.
\end{abstract}

Keywords: Dynamics, Implementation, Basic Education

\section{Introduction}

Education in Indonesia in the past year and a half is different from education in general. Since the issuance of SE Minister of Education and Culture number 4 of 2020 on (03/20). This raises many polemics that must be faced, both by students, teachers and principals (Poerwati, 2015).

The problems that arise are also quite crucial. This has resulted in many experts in the field of education and even a professor competing in finding solutions to new regulations that must be implemented in education in the Covid-19 era. New terms in the world of education have started to emerge, starting from Learning from Home (BDR), Distance Learning (PJJ), online learning (DARING), to the last one is Limited Face-to-face Learning (PTMT).

Learning from home (BDR), students and teachers work together to be able to carry out learning well. In learning from home (BDR) teachers and schools are not required to be able to complete learning according to the syllabus, annual program (PROTA) or semester program (PROMES). The fulcrum in learning from home is to focus on the good running of the learning process between teachers and students (Mantja, 2014).

Teachers also look for students' involvement, creativity, and originality in the classroom while evaluating them. Teaching methods in this discipline include assessing students on their attitudes and abilities, as well as on their knowledge and understanding of the material. That pupils' talents are not only judged from the perspective of their knowledge, but also from the perspective of their capacity to think creatively and innovatively.

The implementation of special curricula is fraught with difficulties for teachers because of the following issues: (1) teachers lack the skills necessary to create lesson plans (RPPs) based on existing provisions and formats; (2) teachers' ability to implement scientific learning methods 
is subpar because teachers' understanding is still at the onset stage (skin only), and teachers are also still utilizing traditional methods of instruction (Ahmad, 2014). In Central Mamuju Regency, the issues of implementing basic education policy during the pandemic will be explored in light of the above explanation.

\section{Literature Review}

\section{Public Policy Implementation}

A policy-making flow certainly goes through several important stages that must be carried out. One of the important stages is policy implementation. (Sanusi, 2014) explains that policy implementation is a process of carrying out an alternative policy that has been decided from several previously designed policy alternatives.

If it is associated with the implementation of policies in the field of education, it can mean that an implementation of educational policies is a process of carrying out an alternative education policy that has been selected and decided. Van meter and Van Horn quoted by Parson (Parsons, 2015) suggest that the implementation of education policy is the overall action taken by individuals or groups and the government or private agencies to carry out a policy that has been made previously in order to achieve educational goals.

From the above understanding, it is clear that policy implementation is carried out after the formulation of the problem, formulation and legitimacy of the policy. The implementation of education policies involves political instruments in deciding which educational policies will be used and implemented. The implementation of education policy will look at the obstacles faced in carrying out an education policy whether an education policy is still implemented or not.

\section{Education Policy}

Policy is a political action that is carried out intentionally with careful and careful thought by a number of officials, organizations, and government agencies to solve problems and produce decisions in accordance with the goals to be achieved. All areas of life have their respective policies to serve as guidelines for acting and limiting behavior, so that they have a clear direction in moving forward.

This policy is no exception in the field of education which is often referred to as educational policy. Education policy is motivated by problems in the field of education. Education policy problems arise when there is a gap between the educational goals that have been set and the reality of education.

(Nugroho, 2014) argue that education policy is the process of formulating strategic steps for the implementation of education by outlining the vision and mission of education in order to achieve the realization of educational goals that are made within a certain period of time. (Kozier, 2016) says that education policy is closely related to the efficiency and effectiveness of the education budget.

From this understanding, it is explained that in formulating educational policies, the vision and mission of national education must be explained to realize the achievement of national education goals. Education policies are set within a certain period of time and can be changed or replaced according to the conditions of the times and needs. Education policies are formulated through a political process to determine plans or strategic steps in providing education.

If it is associated with the implementation of policies in the field of education, it can mean that an implementation of educational policies is a process of carrying out an alternative education policy that has been selected and decided. Van meter and Van Horn quoted by Parson (2015) 
argue that the implementation of education policy is the overall action taken by individuals or groups and the government or private agencies to carry out a policy that has been made previously in order to achieve educational goals (Alwen, 2014).

In Edwards III's view (Subarsono, 2014) policy implementation is influenced by four variables, namely: (1) communication, (2) resources, (3) disposition, and (4) bureaucratic structure. The four variables are related to each other.

\section{Communication}

Implementers must be aware of their responsibilities if policy implementation is to be successful. This information about the policy's aims and objectives must be communicated to the target group in order to limit the likelihood of implementation distortions. A policy's aims and objectives will most likely be met with opposition if they are unclear to the target group, or if they are simply unknown to the target group.

\section{Resource}

Implementation will be ineffective if the policy's contents are not conveyed properly and consistently to the implementor. If the implementor lacks the resources to implement the policy, the policy will be ineffective. They might take the shape of human resources, namely the competence of the implementor, or they can take the form of financial resources. The availability of resources is a critical aspect in the successful execution of policy. Policies will only exist on paper as paperwork if there aren't enough resources.

\section{Disposition}

The disposition of the implementor is defined by the character and traits that he or she has, such as commitment, honesty, and democratic nature. If the implementor has a positive disposition, he or she will be able to carry out policies correctly, as intended by policymakers. If the implementor does not have a positive disposition, the policy implementation process will be unsuccessful.

\section{Bureaucratic Structure}

The organizational structure in charge of putting the policy into effect has a considerable impact on how well the policy is put into effect. The availability of standard operating procedures in any business is one of the most significant structural features of any organization (SOPs). SOP serves as a guideline for every implementer when it comes to action. Organizational structures that are overly lengthy will tend to impair monitoring and result in red tape, which is bureaucratic processes that are convoluted and difficult to understand. As a result, the operations of the organization become more rigid as a result of this.

\section{Methods}

Through the use of case studies, this study takes a descriptive qualitative method. There are a total of 5 informants in this study. Observation, interviews, and documentation are some of the data collecting strategies. Data analysis involves the reduction of data, the display of data, the verification of data, and the formulation of conclusions

\section{Results and Discussion}

\section{Communication}

Implementers must be aware of their responsibilities if policy implementation is to be successful. This information about the policy's aims and objectives must be communicated to the target group in order to limit the likelihood of implementation distortions. A policy's aims 
and objectives will most likely be met with opposition if they are unclear to the target group, or if they are simply unknown to the target group.

\section{Problems that arise simultaneously with the learning system during the pandemic}

Some problem that arise simultaneously with the learning system during the pandemic namely; (1) Psychological online learning has an impact on the lack of psychological relationships between educators and students. The level of closeness between teachers and students runs mechanically, does not involve feelings. Teachers also cannot monitor students' attention to the material provided, whether students are serious about taking lessons or while playing; (2) Virtual learning also raises a lot of bias, for example when the teacher is explaining via zoom, gomeet, webex meet, youtube streaming, etc. suddenly the signal is lost, or unstable, then the conversation will be cut off or even if it runs but stutters, it creates a lot of interference, both from audio and visual aspects. Moreover, if learning through google classroom, e-learning, wag, etc., learning is one-way communication from teacher to student, it does not provide opportunities for student-teacher communication. As a result, the recipients of the message, namely students, will be biased in receiving the material. For students whose cellphone signal is stable, they can receive relatively good learning, but for students who are in locations with poor signal, even no signal at all, then they cannot follow the lesson. Even the most tragic, there are still some students who have not been able to buy an Android cellphone. Or the cellphone has but no quota, even though there is quota assistance from the government, but the distribution is not evenly distributed.

Because online learning is a new learning method, and it is carried out suddenly, both students and teachers have not prepared everything carefully, everything is done with minimal preparation, everything is groping. That was at the beginning of online learning, and in the $2021 / 2022$ school year it seems that the preparation of teachers and students has improved. However, online learning, which has been running for a relatively long time, which is almost 4 semesters, but the transition period from face-to-face learning to online learning has not yet been completed, there are still many obstacles and difficulties, even recently a new problem has emerged, namely fatigue and good burnout. on the part of both teachers and students.

Face-to-face learning is sometimes interspersed with laughter, both between teachers and students and between students, both during the learning process and during breaks. When learning switches to online learning, the stress-relieving laughter is no longer there for both teachers and students. Learning is relatively tense, less relaxed and difficult to insert the stress busting joke. As a result, boredom and fatigue appear, teachers and students are both sluggish, lacking enthusiasm and lack of enthusiasm in learning. This of course will result in the achievement of learning objectives.

\section{Resource}

Implementation will be ineffective if the policy's contents are not conveyed properly and consistently to the implementor. If the implementor lacks the resources to implement the policy, the policy will be ineffective. They might take the shape of human resources, namely the competence of the implementor, or they can take the form of financial resources. The availability of resources is a critical aspect in the successful execution of policy. Policies will only exist on paper as paperwork if there aren't enough resources.

\section{Teacher Problems in Implementing Scientific Learning-Based Learning}

The results of research findings on teacher problems in implementing scientific learning-based learning show: (a) the application of the lecture method and one-way communication from the teacher causes students to become passive; (b) there are still teachers who have never been 
involved in training related to the implementation of a special curriculum, so that technically in class teachers only rely on information they get from colleagues who have attended training or from the internet; (c) teachers are less than optimal in carrying out classroom management on their students, especially low grade students (grade 1); (d) the lack of students' ability to read and write becomes a problem for teachers in delivering learning in the classroom so that students tend to be passive and only listen; and (e) lack of support and motivation from parents for children's development at school which results in the completion of school assignments carried out by parents so that children become irresponsible for their own work.

\section{Teacher Problems in Conducting Learning Assessment}

The results of research findings regarding teacher problems in conducting learning assessments show: (1) the forms of assessment used in assessing student learning outcomes are in the form of simple written assessments such as making simple poems in their own words; then the verbal assessment is carried out with a simple one-way question and answer (from teacher to student); (2) the inactivity of students in participating in the lessons given by the teacher caused by the inability of students to read and write; and (3) the assessment carried out by the teacher only focuses on one aspect, namely the cognitive aspect, while for the affective and psychomotor aspects it is only limited to making an assessment based on observations of student behavior at school

\section{Disposition}

The disposition of the implementor is defined by the character and traits that he or she has, such as commitment, honesty, and democratic nature. If the implementor has a positive disposition, he or she will be able to carry out policies correctly, as intended by policymakers. If the implementor does not have a positive disposition, the policy implementation process will be unsuccessful.

In this study, the researchers discovered that some students struggle to comprehend the content of material that has been presented to them through online media by the teacher. The researchers also discovered that the internet network is occasionally interrupted and that students do not make use of online learning media, as a result of which some subject matter that requires specific learning tools and/or media is not available. The instructor made the most of his or her time.

In order to resolve this issue, the school has attempted to overcome obstacles such as providing instructors with training on the usage of online learning media such as Google Classroom, Google Forms, and the creation of learning films using Camtasia to help them overcome their challenges. In addition, facilities and infrastructure that will be utilized by instructors in the learning process, such as a strengthened internet network, have been constructed to ensure that the distance learning process (online) runs as smoothly as possible.

Teacher attitudes toward students in distance learning can be broken down into a number of categories, including: 1) addressing or perceiving a teacher's personality or character towards the learning process, 2) responding or perceiving a student's personality or character towards the learning process, 3) building students' confidence and self-esteem in the learning process, and 4) providing guidance to students in the learning process who are experiencing difficulties in distance learning.

As a result, in order to carry out their responsibilities properly, teachers must be familiar with and capable of using certain teaching concepts. Among these are the following: (1) teachers must be able to focus students' attention on the subject matter being taught and utilize a variety of media and learning resources; (2) teachers must arouse students' interest in being active in 
thinking and seeking and finding their own solutions to the problems they face; (3) teachers must develop students' attitudes toward fostering social relationships, both among friends and with the wider community; and (4) teachers must instill a love of learning in students.

When a student is studying at home, his learning condition lasts for 9 months, which is an extremely lengthy period of time, causing him to get bored and eventually lazy. Teacher's find it difficult to provide motivation for students during the learning process because students also believe that they are not supervised; in addition, both of their parents are employed, so they have no one to guide them to study during the morning hours, when the learning process takes place until noon. Teachers are having difficulty measuring student learning outcomes because students are having difficulty capturing or understanding each of the indicators presented during the PJJ, despite the fact that the learning indicators have been repeatedly conveyed by the teacher through learning media such as google classroom, according to the problem. Students will occasionally not even open Google Classroom at all, despite the fact that they have received all of the required materials and explanations. The instructor will struggle to assess whether the student has grasped the material in order to meet the set Minimum Completeness Criteria as a result of this (KKM).

\section{Bureaucratic Structure}

The organizational structure in charge of putting the policy into effect has a considerable impact on how well the policy is put into effect. The availability of standard operating procedures in any business is one of the most significant structural features of any organization (SOPs). SOP serves as a guideline for every implementer when it comes to action. Organizational structures that are overly lengthy will tend to impair monitoring and result in red tape, which is bureaucratic processes that are convoluted and difficult to understand. As a result, the operations of the organization become more rigid as a result of this.

The policy of face-to-face learning in schools has been replaced by online or distance learning. However, in early 2021 when the covid-19 vaccine began to be distributed, the discourse to resume face-to-face learning resurfaced. In response to this, the Head of the Education Office explained that the authority to provide face-to-face learning was left to each region. Face-toface learning can be held while taking into account health protocols. There are several conditions that must be met for every school that will hold face-to-face learning including the permission of the parents of students through the committee, the readiness of the school to hold face-to-face learning with strict health protocols, and obtaining permission from the local government through the COVID-19 task force. Currently, a pilot project for the provision of face-to-face learning in schools for each level will be carried out, of course with a strict and structured school selection mechanism.

\section{Conclusion}

The dynamics of implementing basic education in Central Mamuju Regency includes 4 aspects, namely (1) communication that raises problems that coincide with the learning system during the pandemic, where online learning psychologically affects the lack of psychological relationships between educators and students. (2) Resources include teacher problems in implementing Scientific Learning-Based Learning and in providing learning assessments. (3) Students who are less able to comprehend the content of the material that has been presented through online media by the teacher, the internet network being occasionally disrupted, and the lack of use of online learning media, such that some subject matter that requires specific learning tools and/or media cannot be used are all examples of dispositions that can be observed. The instructor made the most of his or her time. (4) Bureaucratic structure, face-toface learning policies in schools have been replaced with online or distance learning. However, 
in early 2021 when the covid-19 vaccine began to be distributed. There are several conditions that must be met for every school that will hold face-to-face learning including the permission of the parents of students through the committee, the readiness of the school to hold face-toface learning with strict health protocols, and obtaining permission from the local government through the COVID-19 task force. Currently, a pilot project for the provision of face-to-face learning in schools for each level will be carried out, of course with a strict and structured school selection mechanism.

\section{References}

Ahmad. (2014). Roblematika Kurikulum 2013 dan Kepemimpinan Instruksional Kepala Sekolah. Jurnal Pencerahan, 8(2), 98-108.

Alwen, B. (2014). Pendidikan Multikultural: Dalam Perspektif Inovasi Kurikulum di Indonesia. Jurnal Inovasi Kebijakan Universitas Negeri Padang, 2(1).

Kozier, B. (2016). Konsep Derivasi dan Implikasinya. PT. Gramedia Pustaka Utama Persada.

Mantja, W. (2014). Etnografi: Desain Penelitian Kualitatif Pendidikan dan Manajemen Pendidikan. Elang Mas.

Nugroho, R. D. (2014). Kebijakan Publik: Formulasi, Implementasi,. Evaluasi. PT. Elex Media Komputindo.

Parsons, T. (2015). Social Structure \& Person (Terjemahan). Free Press.

Poerwati, A. (2015). Panduan Memahami Kurikulum. PT Prestasi Pustakaraya.

Sanusi, A. (2014). Studi Pengembangan Model Pendidikan Profesional. Tenaga Kependidikan. IKIP Bandung Departemen.

Subarsono. (2014). Pembagian Pendekatan Pertumbuhan Ekonomi. Pengantar Ekonomi Makro dan Mikro. BPFE 